\title{
Identification of ecogeographical gaps in the Spanish Aegilops collections with potential tolerance to drought and salinity
}

\author{
Rosa M Garcia ${ }^{\text {Corresp., }}$ 1 , Mauricio Parra-Quijano $^{2}{ }^{\text {, }}$ Jose M Iriondo $^{3}$ \\ ${ }^{1}$ Centro Nacional de Recursos Fitogenéticos (CRF-INIA), Alcalá de Henares, Madrid, Spain \\ 2 Facultad de Ciencias Agrarias, Universidad Nacional de Colombia, Bogotá D.C., Colombia \\ 3 Área de Biodiversidad y Conservación, Universidad Rey Juan Carlos, Móstoles, Madrid, Spain \\ Corresponding Author: Rosa M Garcia \\ Email address: rosamaria.garcia@inia.es
}

Drought, one of the most important abiotic stress factors limiting biomass, significantly reduces crop productivity. Salinization also affects the productivity of both irrigated and rain-fed wheat crops. Species of genus Aegilops can be considered crop wild relatives (CWR) of wheat and have been widely used as gene sources in wheat breeding, especially in providing resistance to pests and diseases. Five species (Ae. biuncialis, Ae. geniculata, Ae. neglecta, Ae. triuncialis and Ae. ventricosa) are included in the Spanish National Inventory of CWRs. This study aimed to identify ecogeographic gaps in the Spanish Network on Plant Genetic Resources for Food and Agriculture (PGRFA) with potential tolerance to drought and salinity. Data on the Spanish populations of the target species collected and conserved in genebanks of the Spanish Network on PGRFA and data on other population occurrences in Spain were compiled and assessed for their geo-referencing quality. The records with the best geo-referencing quality values were used to identify the ecogeographical variables that might be important for Aegilops distribution in Spain. These variables were then used to produce ecogeographic land characterization maps for each species, allowing us to identify populations from low and non-represented ecogeographical categories in ex situ collections. Predictive characterization strategy was used to identify 45 Aegilops populations in these ecogeographical gaps with potential tolerance to drought and salinity conditions. Further efforts are being made to collect and evaluate these populations. 
1 Identification of ecogeographical gaps in the Spanish Aegilops collections with potential

2 tolerance to drought and salinity

3 Rosa María GARCÍA ${ }^{1}$, Mauricio PARRA-QUIJANO ${ }^{2}$, Jose María IRIONDO

$4{ }^{1}$ Centro Nacional de Recursos Fitogenéticos (CRF-INIA), Alcalá de Henares, Madrid, Spain

$5 \quad{ }^{2}$ Facultad de Ciencias Agrarias, Universidad Nacional de Colombia, Bogotá D.C., Colombia

$6 \quad{ }^{3}$ Área de Biodiversidad y Conservación, Universidad Rey Juan Carlos, Móstoles, Madrid, Spain.

7

8 Corresponding Author:

9

10

Rosa María García ${ }^{1}$

11 Email address: rosamaria.garcia@inia.es 


\section{Abstract}

Drought, one of the most important abiotic stress factors limiting biomass, significantly reduces crop productivity. Salinization also affects the productivity of both irrigated and rain-fed wheat crops. Species of genus Aegilops can be considered crop wild relatives (CWR) of wheat and have been widely used as gene sources in wheat breeding, especially in providing resistance to pests and diseases. Five species (Ae. biuncialis, Ae. geniculata, Ae. neglecta, Ae. triuncialis and Ae. ventricosa) are included in the Spanish National Inventory of CWRs. This study aimed to identify ecogeographic gaps in the Spanish Network on Plant Genetic Resources for Food and Agriculture (PGRFA) with potential tolerance to drought and salinity. Data on the Spanish populations of the target species collected and conserved in genebanks of the Spanish Network on PGRFA and data on other population occurrences in Spain were compiled and assessed for their geo-referencing quality. The records with the best geo-referencing quality values were used to identify the ecogeographical variables that might be important for Aegilops distribution in Spain. These variables were then used to produce ecogeographic land characterization maps for each species, allowing us to identify populations from low and non-represented ecogeographical categories in ex situ collections. Predictive characterization strategy was used to identify 45 Aegilops populations in these ecogeographical gaps with potential tolerance to drought and salinity conditions. Further efforts are being made to collect and evaluate these populations.

\section{$\underline{\text { Introduction }}$}

Drought is one of the most important abiotic stress factors limiting biomass (Araus et al., 2002), and consequently, it significantly reduces crop productivity (Lambers et al., 2008; Noorka \& Heslop-Harrison, 2014). Wheat (Triticum spp.), the second most-produced cereal in the world (FAO, 2013a), can be severely affected by this type of abiotic stress. For instance, in 2009, wheat yield in Kenya dropped by $45 \%$ due to drought, compared to 2010 production that took place under a good crop season. Australia, which suffered multi-year droughts between 2002 and 2010, experienced a 46\% drop in wheat yield in 2006 (FAO, 2013b).

Another threat to both irrigated and rain-fed wheat crops is salinization (Mujeeb-Kazi \& Diaz de Leon, 2002). Salt stress and drought have similar effects on structural and functional aspects of plants (Al-maskri et al., 2014), but salt stress also causes ion toxicity and ionic imbalance (Hameed et al., 2011). Drought stress decreases photosynthetic efficiency, greatly reducing growth and development (Al-maskri et al., 2014). Salt-affected soils occur in all continents and under almost all climatic conditions. However, they are more widely distributed in arid and semiarid regions than in humid regions (Abrol et al., 1988). Many crops in these areas are grown under irrigation, but inadequate irrigation management may lead to secondary salinization (Glick et al., 2007). Large areas of naturally saline and alkaline soils account for $6 \%$ of the world's 
67 land surface. These saline soils have never been cultivated because present major crops are salt-

68

69 sensitive (Fita et al., 2015).

The species of genus Aegilops have been widely used as gene sources in wheat breeding, especially in providing resistance to pests and diseases such as leaf, stem and stripe rusts (Puccinia recondita, P. graminis and P. stiiformis) or hessian fly (Mayetiola destructor). Numerous studies have searched for drought and salt stress tolerant genotypes. For instance, Xing et al. (1993) studied the potential of some Aegilops species, including Ae. ventricosa Tausch, as gene donors in breeding for salt tolerance. Subsequent studies proposed Ae. ovata L. as a source of salt tolerance in wheat (Farooq, 2002) and determined that Ae. ovata and Ae. biuncialis Vis. have wide genetic variation for salt tolerance (Colmer et al., 2006). Molnár et al. (2004) compared the physiological and morphological responses to water stress in Ae. biuncialis and Triticum aestivum L. genotypes, and concluded that Ae. biuncialis genotypes from dry habitats have greater drought tolerance than wheat, making them good candidates for improving drought tolerance in this crop. Mondini et al. (2014) identified SNPs variants conferring salt tolerance in durum wheat. Due to their present and potential use as gene donors in wheat breeding, Aegilops species can be considered crop wild relatives (CWR) of wheat (Heywood et al., 2007). Five of these species (Ae. biuncialis, Ae. geniculata Roth, Ae. neglecta Req. ex Bertol., Ae. triuncialis L. and Ae. ventricosa) are included in the Spanish National Inventory of CWRs (Rubio et al., 2013).

Ecogeographical land characterization (ELC) map can be helpful in determining different adaptive scenarios of a species in a given territory. An ELC map represents the different ecogeographical conditions in which a particular species or group of species occurs, using some variables of high importance in the species' distribution likely to be determinant for the adaptive landscape (Parra-Quijano et al., 2012a).

Parra-Quijano et al. (2008) developed an ELC map for Peninsular Spain and the Balearic Islands, using different sources of ecogeographical information. The ability of the ELC map to discriminate different areas with different adaptive pressures was tested with eight crop and CWR species. They found that the ELC map had an effective discriminatory capacity to delineate adaptive scenarios. Because the efficacy in detecting plant adaptation was heterogeneous for the species analyzed, it was concluded that the application of ecogeographical maps for detecting plant adaptation may be better approached through an ad-hoc ELC map generation for each target species. The ELC concept is detailed in depth in Parra-Quijano et al. (2012a), and several applications related to the collection, conservation and efficient use of plant genetic resources have been developed (e.g., Parra-Quijano et al., 2012a; Parra-Quijano et al., 2012b; Thormann et al., 2016).

Gap analysis has been widely applied for conservation purposes (Maxted et al., 2008). For instance, Ramírez-Villegas et al. (2010) applied a gap analysis methodology to collect the crop genepool of Phaseolus beans and evaluated conservation deficiencies at three different levels 
105 (taxonomic, geographic and environmental). Khoury et al. (2010) reviewed global crop and 106 regional conservation strategies and recognized the importance of filling gaps in genebanks of 107 plant genetic resources. Recently, Shehadeh et al. (2014) carried out a gap analysis of Lathyrus 108 L. species. In this study, predictive distribution maps for each Lathyrus taxon were produced 109 based on climatic data, and ex situ conservation gaps were identified as regions where the species 110 was predicted to occur but seed accessions had not been previously collected, or, alternatively, 111 the species was under-sampled.

112 Optimized Collecting Design (OCD) is a technique described by Parra Quijano et al. (2012b) 113 that involves the identification of ecogeographical gaps for a target species in a target ex situ 114 genebank. Based on the premise that genetic adaptation is achieved through natural selection 115 acting upon particular limiting environmental conditions, this technique aims to improve the 116 genetic representativeness of genebank accessions by improving their ecogeographical representativeness. Like other gap analysis techniques, OCD compares the collecting locations of the target species accessions currently held in the genebanks and the species' occurrence data from external sources (spatial gaps). It then uses ELC maps to detect adaptive scenarios not represented in the target ex situ genebank. Using ELC maps to design collecting strategies can help to include accessions from marginal or under-represented environments that may contain important traits related to adaptations to biotic and abiotic stress.

123

Another interesting issue for genebank managers and stakeholders is the identification of genotypes that can have a specific use in plant breeding. The Focused Identification of Germplasm Strategy (FIGS) is a useful approach for screening large germplasm collections to identify sets of accessions with a high probability of containing specific target traits based on the ecogeographical information of the sites where the populations were collected (Mackay \& Street, 2004). If we know where a set of ex situ accessions has evolved, or at least where they have grown for a period long enough for adapted genotypes to have been selected, we can establish relations or patterns between the environmental conditions of the site and the presence or absence of the target trait. We can then make predictions on non-evaluated germplasm (Mackay \& Street, 2004).

In recent years, FIGS has been successfully used to identify sources of resistance to sunn pest in wheat in Syria (El Bouhssini et al., 2009) and to Russian wheat aphid in bread wheat (El Bouhssini et al., 2011). FIGS has also been used to identify traits related to abiotic stresses, such as drought adaptation in Vicia faba L. (Khazaei et al., 2013). These studies selected accessions from an ecogeographically-characterized collection that complied with certain values or ranges for the characterized variables, set by the researchers based on their knowledge of the species. Other FIGS approaches can be used to identify accessions of potential interest, when the trait under consideration cannot be directly related to an ecogeographical variable. In this case, partial evaluation data from the target collection are required to detect a reliable relationship between the ecogeographical variables and the trait of interest. This approach has been successfully applied by Thormann et al. (2016) and Endresen et al. (2012), who identified sources of 
144 resistance to stem rust in bread and durum wheat, and by Bari et al. (2011, 2014), who predicted resistance to stem rust and stripe rust in accessions of wheat landraces.

A broader concept has recently been developed to identify germplasm with a high probability of containing specific target traits, named "predictive characterization". This term comprises a set of approaches that use geographic and environmental data to search for particular traits in a usually large set of populations, not only accessions and landraces but also CWR (Thormann et al., 2014). This search can be carried out by means of the ecogeographical filtering method or the calibration method (Thormann et al., 2014).

Using these ecogeographical approaches, we aimed to apply OCD and predictive characterization techniques to the optimization of the ex situ collection of crop wild relatives of wheat in the national reference genebank of Spain. The objectives of this study were: (1) to identify spatial and ecogeographical gaps within Spain land which could be present in the Spanish genebank collections of Aegilops biuncialis, Ae. geniculata, Ae. neglecta, Ae. triuncialis and Ae. ventricosa to design an optimized systematic collection strategy of crop wild relatives of wheat for the national genebank of Spain; and (2) to identify non-collected populations that might be of potential interest because of their tolerance to drought and salinity within the group of ecogeographical gaps for each species in order to prioritize their collection.

\section{Materials \& Methods}

\section{Target species}

The targeted species were Ae. biuncialis Vis., Ae. geniculata Roth, Ae. neglecta Req. ex Bertol., Ae. triuncialis L. y Ae. ventricosa Tausch. Species names were standardized using van Slageren (1994). Regarding their distribution in Spain, all of them are found in the Mediterranean biogeographical region. Ae. biuncialis is also found in the Macaronesian region, whereas Ae. geniculata can also be found in the Atlantic region. Table 1 provides a summary of information on distribution, autecology and mating system of each species.

Table 1 Autecology and mating system of the targeted Aegilops species. Information obtained from Van Slageren (1994) unless otherwise stated

\section{Species datasets}

Data on Spanish populations of Aegilops spp. collected and conserved in the genebanks of the Spanish Network of Plant Genetic Resources for Food and Agriculture (PGRFA) (hereinafter "accessions") were obtained from the Spanish Inventory of Plant Genetic Resources (available at http://wwwx.inia.es/inventarionacional/, accessed 26 May 2015). 
178 Data on population occurrences from additional sources (hereafter "external sources") were

179

180

181

182

183

184

185

186

187

188

189

190

191

192

193

194

195

196

197

198

199

200

201

202

203

204

205

206

207

208

209

210

211

212

213

obtained from the Global Biodiversity Information Facility (GBIF; available at http://www.gbif.org/, accessed 14 February 2014) and Anthos (available at http://www.anthos.es/, accessed 25 June 2015) databases. Populations conserved in ex situ genebanks that do not belong to the Spanish Network on PGRFA were also considered external sources. Accessions missing in the Spanish National Inventory, provided by the Plant Genetic Resources National Centre of the Spanish National Institute for Agricultural and Food Research and Technology (http://wwwx.inia.es/coleccionescrf), were considered external sources as well.

All accessions and external sources without geographic coordinates were removed. We also removed external sources with geographic coordinates expressed in decimal degrees with less than two decimals in both latitude and longitude or without textual description on the occurrence site, and external sources with geographic coordinates expressed in UTM with lower resolution than $1 \times 1 \mathrm{~km}$. Passport and presence data were standardized to CAPFITOGEN data formats which is basically the Multi-Crop Passport Descriptor (FAO-Bioversity, 2012) plus four additional administrative fields for collecting or presence site description (Parra-Quijano et al., 2015).

Georeferencing data of both accessions and external sources were cleared of spatial intraspecific duplicates. We considered that species occurrences less than $1 \mathrm{~km}$ apart belonged to the same population, following Iriondo et al. (2009). Therefore, these population occurrences were considered spatial duplicates and only one of them was considered.

Accessions and external sources free of spatial duplicates were subjected to a geo-referencing quality evaluation using GEOQUAL from the CAPFITOGEN toolkit (Parra-Quijano et al., 2015). We set the quality threshold in TOTALQUAL100 $=80$, so only records with quality values above this threshold were considered in subsequent analyses.

\section{Selection of ecogeographical variables}

Ecogeographical information was extracted for each occurrence site from raster layers with a 30 arc-second resolution and classified into three ecogeographical components: bioclimatic variables (37), edaphic variables (16) and geophysic variables (4) (see Supplemental Table 1).

The variables that might be the most relevant for each species in each ecogeographical component were then identified using the SelecVar tool from CAPFITOGEN (Parra-Quijano et al., 2015). SelecVar extracts information from the ecogeographical variables (layers) to the occurrence sites and assesses the importance of each variable in generating different adaptive scenarios for a species (Parra-Quijano et al., 2015). It estimates variable importance according to the random forest classification (RFC) and detects redundant variables through bivariate correlation analysis. The RFC analysis provides a ranking of the most important variables for establishing ecogeographical categories, placing variables with a higher mean decrease in 
214 accuracy in the first positions (Cutler et al., 2007). Rankings were obtained for each

215 ecogeographical component for each species. Bivariated correlation analysis detected correlated

216 variables in the top fifteen variables of the RFC ranking. Variables with Pearson correlation

217 coefficient $>|0.50|$ and $p$-value $<0.05$ in the same ecogeographical component were identified

218 and removed.

\section{Generation of the ELC maps}

220 An ecogeographical land characterizacion map or ELC map is a representation of the different adaptive scenarios of a species (Parra-Quijano et al., 2012a). In this study, we generated an adhoc ELC map for each target taxa assuming that each taxa may respond differently to the environment. Thus, we considered that this approach would provide better results than those obtained from the generation of a single ELC map for all the taxa.

225

226

227

228

229

230

231

232

233

234

235

236

237

238

239

240

241

242

243

244

245

246

247

248

249

The top three bioclimatic, three edaphic and two geophysic variables in the rankings of variable importance (i.e., the ecogeographical variables suggested as relevant in the species distribution) were considered in generating the ELC map for each species. The variables latitude and longitude were included as two additional geophysic variables to obtain maps with spatially aggregated categories. The "elbow" method was used to create the ecogeographical categories. This is a simple system which uses $\mathrm{K}$ means as a clustering algorithm where the cut-off point is determined on the basis of the decrease in the sum of the intra-group squares (Ketchen \& Shook, 1996). The optimal number of categories is reached when the decrease in the intra-group sum of squares in a range of $n$ and $n+1$ groups is less than 50\%. ELC maps were generated for each species using the ELCmapas tool of the CAPFITOGEN toolkit (Parra-Quijano et al., 2015) and the following parameters: 30 -arc-second cell size resolution and 8 clusters as the maximum number of categories allowed per ecogeographical component (bioclimatic, edaphic and geophysic).

\section{Identification of spatial and ecogeographical gaps and prioritization of occurrence sites for future collections in Aegilops}

Spatial gaps were identified based on occurrence site coordinates. For each species, locations cited by external sources more than $1 \mathrm{~km}$ apart from accessions were considered spatial gaps. An ecogeographical representativeness analysis of the existing germplasm collections was then carried out to identify ecogeographical gaps (ELC map categories not represented in ex situ genebanks where the species occurs).

Areas with a high occurrence of external sources (listed as ecogeographical gaps) and a low occurrence of accessions were considered priority collecting sites, as were areas corresponding to the ELC map categories with a low frequency for the species and in the territory. Occurrence data from external sources were then ranked according to their priority of collection based on the 
250 frequency of each ELC map category in the study area, the frequency of each species in each

251 ELC map category and the differences between the external sources data set and the accessions

252 data set. Ecogeographical gap identification and prioritization of external sources occurrence

253 data for germplasm collection were performed using the Representa tool of CAPFITOGEN

254 (Parra-Quijano et al., 2015). External sources which occurred in ecogeographical categories not

255 represented by the corresponding species in the genebanks of the Spanish Network, i.e., external

256 sources reclassified by the Representa tool within the range from 1 to 4, were considered high

257 priority ecogeographical gaps.

258

259 Selection of collection sites for traits of tolerance to drought and salinity

260 To search for populations with a higher probability of containing phenotypes with a high

261 tolerance to drought and salinity, the external sources considered high priority ecogeographical

262 gaps were filtered using the Lang aridity index $\left(\mathrm{AI}_{\mathrm{L}}\right)$ and topsoil salinity. The Lang aridity index

263 was calculated as:

$\mathrm{AI}_{\mathrm{L}}=$ Annual precipitation / (Annual mean temperature)

265

266

267

268

269

Following the ecogeographical filtering technique of predictive characterization (Thormann et al., 2016), we selected populations occurring in sites with $\mathrm{AI}_{\mathrm{L}}<40$. We considered the $20 \%$ of the populations with the lowest Lang aridity index and the highest topsoil salinity (HWS Database, 2012) values to be the fraction of interest for each of the five target species.

The process followed to reach the objectives of the study is shown in Fig. 1.

Fig. 1 Process carried out to identify ecogeographical gaps in the Spanish Aegilops germplasm collections with potential tolerance to drought and salinity

\section{$\underline{\text { Results }}$}

\section{Germplasm collection sites and presence data}

Data pre-processing showed that the most frequently recorded species and those with the widest distribution in Spain were Ae. geniculata and Ae. triuncialis. The least frequently recorded species was Ae. biuncialis. Table 2 shows the number of accessions and occurrence data from external sources for each species before and after clearing spatial duplicates and applying the geo-referencing quality threshold. The percentage of spatial duplicates in the occurrence data of external sources ranged from 47 to 65\%, recorded for Ae. biuncialis and Ae. geniculata, respectively. Applying the geo-referencing quality threshold decreased the number of nonduplicated populations to 6 and $21 \%$ in the occurrence data of external sources of Ae. biuncialis and Ae. geniculata, respectively. 
284 Table 2 Number of Aegilops germplasm accessions and occurrence records from external

285

286

287

288

289

290

291

292

293

294

295

296

297

298

299

300

301

302

303

304

305

306

307

308

309

310

311

312

313

314

315

316

317

sources with geographical coordinates included in the study before and after clearing spatial duplicates and filtering by the geo-referencing quality threshold

The species records for Ae. geniculata (accessions + external sources) remaining after the clearing of spatial duplicates and the geo-referencing quality threshold are shown in Fig. 2. The maps of the other Aegilops species are shown in Supplemental Figures 1-4.The populations represented by accessions in the genebanks are not homogeneously distributed in the studied area (see Fig. 2a), nor are they more frequently located in the areas where the presence of these species was reported by external sources. For instance, $66 \%$ of the preserved populations of the five target species (226 out of 345 populations) were collected in the autonomous communities of Extremadura and Castilla-La Mancha, whereas only 10\% of the external sources (272 out of 2614 populations) are located in these two communities. The populations reported by external sources are abundant in the south of Spain, in the provinces on the eastern coast and in the autonomous community of Navarra.

Fig. 2 Location of (a) origin of germplasm accessions in Peninsular Spain, the Balearic Islands and the Canary Islands and (b) population occurrence from external sources of Ae. geniculata

\section{Identification of variables of importance}

The variables selected for each studied species and ecogeographical component (bioclimatic, geophysic and edaphic variables) are shown in Table 3. The variables isothermality and altitude were selected in four of the five studied species.

Table 3 Variables selected in each Aegilops species and ecogeographical component according to the importance function of the random forest approach (see Supplemental Table 1 for variable description)

\section{Generation of ELC maps}

The ELC map obtained for Ae. geniculata is shown in Fig. 3. The maps of the other Aegilops species are shown in Supplemental Figures 5-8. The number of ecogeographical categories generated in the maps ranged between 26 (in the ELC map for Ae. biuncialis) and 27 (in the maps for the other species). The environmental characteristics of the different categories of each ELC map are summarized in Supplemental Table 2.

Fig. 3 ELC map of Ae. geniculata for Peninsular Spain, the Balearic Islands and the Canary Islands. The environmental characteristics of the different categories are described in Supplemental Table 2 
Identification of spatial and ecogeographical gaps in the Aegilops germplasm collections

320 Among the populations reported by external sources, 2571 were identified as spatial gaps. Ae.

321

322

323

324

325

326

327

328

329

330

331

332

333

334

335

336

337

338

339

340

341

342

343

344

345

346

347

348

349

350

351

352 geniculata was identified as the species with the largest number of spatial gaps. As seen in Table 4, 393 populations were identified as priority ecogeographical gaps in the registered genebank collections of Aegilops in the Spanish National Inventory of Plant Genetic Resources. These 393 populations occur in ecogeographical categories that are not represented by the corresponding species in the Spanish Network. Ae. geniculata, the first-ranking species in number of spatial gaps, was also identified as the species with the largest number of ecogeographical gaps. Ae. biuncialis, the species with the lowest number of preserved accessions (Table 2), is also the species whose ex situ ecogeographical representativeness needs the most improvement, as $80 \%$ of the available external sources were identified as high priority gaps. On the contrary, only $10 \%$ of the analyzed external sources of Ae. geniculata and Ae. triuncialis, the two species with the highest number of preserved accessions (Table 2), were identified as high priority ecogeographical gaps.

Table 4 Number of population occurrences from external sources of Aegilops subjected to representativeness analysis and number of spatial gaps and priority ecogeographical gaps identified in Spain

The geographic distribution of the populations identified as priority ecogeographical gaps of $A e$. geniculata is shown in Fig. 4. The maps of the other Aegilops species are shown in Supplemental Figures 9-12.

Fig. 4 Location of the Ae. geniculata populations identified as priority ecogeographical gaps in Spain

Including germplasm from priority ecogeographical gaps in the genebanks of the Spanish Network on PGRFA would significantly improve their ecogeographical representativeness (number of ecogeographical categories not currently represented in the Spanish Network, Table 5). The obtained percentage of ELC categories represented in the Spanish Network ranged from $8 \%$ to $48 \%$ in Ae. biuncialis and Ae. geniculata, respectively. As the priority ecogeographical gaps belong to categories not yet represented, their collection and conservation would contribute to increasing the percentage of ELC categories represented in the Spanish Network to values ranging from $27 \%$ to $70 \%$ in Ae. biuncialis and Ae. neglecta, respectively.

Table 5 Number of ELC categories for Aegilops currently represented in the Spanish Network and potential increase (\%) in representativeness after collecting priority ecogeographical gaps

\section{Selection of priority collecting sites for traits of tolerance to drought and salinity}


353 Among the 393 populations identified as priority ecogeographical gaps, 223 populations inhabit 354 sites with a Lang index value $<40$, and thus are potentially adapted to arid environments (Table 355 6). The geographic location of these accessions is shown in Fig. 5a. The 20\% of these 223 356 populations with the highest values of topsoil salinity for each species $(20 \%)$ and their 357 geographical distribution are shown in Table 6 and Fig. 5b, respectively. These 45 populations

358 (Table 6) constitute the predictive characterization (PC) subset of Aegilops populations of 359 potential interest due to their potential tolerance to drought and salinity, in addition to

360 representing ecogeographical gaps. Table 7 contains complete information on the geographic location, the Lang aridity index and topsoil salinity of the populations included in this PC subset.

Table 6 Priority ecogeographical gaps of targeted Aegilops species selected for drought and salinity tolerance in Spain

Fig. 5 Location of (a) priority ecogeographical gaps of Aegilops in Spain that occur in sites where the Lang aridity index is $<40$, and (b) priority ecogeographical gaps that occur in sites where the highest salinity values are also found

Table 7 Geographic description of the Spanish Aegilops populations selected as potentially tolerant to drought and salinity

The inclusion of the predictive characterization subset populations in the genebanks of the Spanish Network on PGRFA would improve their ecogeographical representativeness between $7 \%$ and $11 \%$ (Table 8 ).

Table 8 Number of ELC categories of Aegilops species currently represented in the Spanish Network and potential increase (\%) in representativeness by collecting populations of the predictive characterization (PC) subset

\section{$\underline{\text { Discussion }}$}

\section{The preprocessing of presence data}

The quality of geo-referencing in spatial analysis is very important to obtain reliable results. Maldonado et al. (2015), who studied the role of natural history collections in unveiling correct patterns of biodiversity and distribution, concluded that geographic inaccuracy affects diversity patterns more than taxonomic uncertainties. Similarly, Graham et al. (2008) evaluated how uncertainty in geo-references and associated location errors in occurrences influence species distribution modeling and found that models run with data subject to random location errors resulted in less accurate models in many species. However, few studies on genetic diversity or taxonomic spatial distribution describe robust methods to ensure the quality of geo-referenced data. Some authors, such as Fielder et al. (2015, 2016), excluded records dated from before 1970, records lacking both coordinates and location descriptions and records with a precision lower 
388

than $4 \mathrm{~km}^{2}$. Ramírez-Villegas et al. (2010) carried out a process to verify and correct the coordinates using BioGeomancer, Google Earth and highly detailed maps. Khoury et al. (2015) cross-checked the coordinates to country and verified that they occurred on land. After that, occurrence data were evaluated for correctness with experts on the target species. In our study, apart from removing accessions and external sources with low accuracy according to the established criteria, the assessment of the quality of the georeferenced data allowed us to identify the records with the highest quality. In this sense, the final number of records included in the analysis (considering both accessions and external sources) ranged between $30 \%$ and $53 \%$ of the initial number of records (for Ae. geniculata and Ae. biuncialis, respectively). This selective use of records, which complies with the minimum standards of georeferencing quality, reduces the probability of generating erroneous results in the analysis.

\section{Identification of spatial and ecogeographical gaps}

Spatial bias in collecting activities and chorological studies often affects the spatial distribution of the species, as shown in Maldonado et al. (2015). In our study, the spatial distribution of the accessions could reflect the intensity of collecting activities rather than the real distribution of the species (see Fig. 2a). A recent project focused on collecting Aegilops germplasm may have contributed to the difference observed in the numbers of accessions between areas because it was focused on the collection of Ae. geniculata, Ae. neglecta, Ae. triuncialis and Ae. ventricosa in the west, center and south of the country.

In a similar way, the distribution of the external sources of the targeted species (Fig. 2 b) shows a higher number of populations in some areas of the country, such as the autonomous communities of Navarra and Valencia. This may reflect a higher intensity of chorological studies rather than a higher presence of the species in these areas. The fact that the distribution of external sources is different from accessions indicates lack of collection missions in particular areas, for example the Canary Islands.

It is worthy to note that the real distribution of the species could be more extensive that the distribution shown by the combination of external sources and accessions. For instance, the target species might occur in places completely outside of the parameters used that are based on historical information. In this sense, it should be clearly understood that the efficacy of this collecting methodology, like any other, heavily depends on how well currently available chorological data represents the real distribution of the species.

Several chorological studies involving the spatial gap analysis of different species have been used as a guide for germplasm collecting. For instance, Maxted et al. (2008) identified ex situ conservation gaps in Aegilops germplasm collections as regions where the species were predicted to occur according to species distribution models, but previous collection had not taken place. In this study, the priority of germplasm collecting for each of Aegilops species was ranked high, 
425

426

427

428

429

430

431

432

433

434

435

436

437

438

439

440

441

442

443

444

445

446

447

448

449

450

451

452

453

454

455

456

457

458

459

460

461

462

medium or low, according to the number of germplasm accessions already conserved ex situ and the number of predicted under-sampled regions. Shehadeh et al. (2013) followed this methodology to carry out a gap analysis of Lathyrus L. species. Another recent methodology for gap analysis was described in Ramírez-Villegas et al. (2010) and applied to wild taxa of the Phaseolus genepool. It involves an eight-step process to evaluate conservation deficiencies at three different levels (taxonomic, geographic and environmental) through the calculation of sampling, geographic and environmental representativeness scores. This methodology was also applied in Castañeda-Álvares et al. (2015) to identify ex situ conservation priorities for the wild relatives of potato and in Khoury et al. (2015) in their study of the CWR pigeonpea.

The ex situ conservation gap analyses in these studies were obtained by overlapping the distribution maps of germplasm accession data and predictive distribution maps generated from the climatic envelope data of the accessions, or of both accessions and external sources.

With regard to identifying spatial gaps, Ramirez-Villegas et al. (2010) assessed the adequacy of geographic coverage of genebank accessions by means of a geographical representativeness score (GRS). This score is the geographic coverage of germplasm collections (modeled using the circular area statistic with a $50 \mathrm{~km}$ radius value) divided by the potential distribution coverage of the taxon under analysis. The higher the GRS is, the greater the representativeness of genebank collections is in relation to the potential distribution of the taxon. Fielder et al. $(2015,2016)$ also used this methodology to assess the geographical representativeness in their studies on the conservation of CWR in England and Scotland. They established a threshold of five accessions above which CWR are considered sufficiently represented in ex situ genebanks. In these geographic coverage assessments, the use of the potential distribution coverage of a taxon can lead to low GRS values due to the presence of false positives in the model (i.e. predicted locations with no real population occurrence) even though they have a good spatial representation in the ex-situ collections. In our study, we adopted a more conservative approach based only on recorded occurrences to avoid this problem.

With regard to identifying ecogeographical gaps, the exclusive use of species distribution models to develop strategies for germplasm collecting may also lead to the over-representation of some adaptive scenarios because these models guide collectors to the species' most preferred habitats (Parra-Quijano et al., 2012b).

On the other hand, predictive species distribution models based on bioclimatic information only offer a partial view of plant abiotic adaptation. In our study, we generated ecogeographical land characterization maps using the values of bioclimatic, geophysic and edaphic variables at species occurrence sites to suggest the potential adaptive scenarios of the species. The representativeness analysis, based on the comparison of the ELC categories of the accessions and the external sources considered spatial gaps, helped us to select priority collecting sites, avoid overrepresentation and identify populations from low and non-represented ecogeographical categories. This allowed us to identify populations in marginal environments in the species' 
463

464

465

466

467

468

469

470

471

472

473

474

475

476

477

478

479

480

481

482

483

484

485

486

487

488

489

490

491

492

493

494

495

496

497

498

range, where interesting traits related to abiotic stress tolerance may be found. The easy-to-use tools employed in this study (i.e. CAPFITOGEN tools, Parra-Quijano et al., 2015) allow genebank curators and technicians in charge of collecting activities to develop their own germplasm collecting design based on spatial and ecogeographical analyses.

A sound ecogeographical gap analysis requires that the resolution of the ecogeographical layers used is in a comparable scale to the resolution used for the chorological data. That is why, in our study, chorological data and ecogeographical data were filtered and/or chosen to accommodate to a similar resolution.

When trying to improve the ecogeographical representativeness of an ex situ germplasm collection, we would expect that the lower the number of accessions of a species in a genebank is, the higher the probability of improving its ecogeographical representativeness by collecting seeds from new populations. However, this may not be the case. For instance, Ae. biuncialis, the target species with the lowest number of accessions in this study, is also the species with the lowest potential percentage of representativeness improvement. This is probably because the existing accessions are a good representation of the few ecogeographical categories where the presence of the species is recorded.

Including populations identified as priority ecogeographical gaps in the genebank collections of the Spanish Network on PGRFA would qualitatively improve ecogeographical representativeness, with increases in the percentages of ELC categories represented in the Network between $27 \%$ and $70 \%$. Such increases are higher than those obtained in the Lupinus species collecting activities described in Parra-Quijano et al. (2012b), which ranged between 7\% and $11 \%$. However, it should be noted that the representativeness of Lupinus species, in the reference germplasm collection before the optimized collecting activities were carried out, was higher than in the case of the targeted Aegilops species.

\section{Selection of priority collecting sites for traits of tolerance to drought and salinity}

The search for the $20 \%$ of the populations adapted to arid environments and with the highest topsoil salinity values allowed us to identify populations that occur in sites in the western Mediterranean distribution of the targeted species with the highest salinity values, according to the work on saline and sodic soils in the European Union by Tóth et al. (2008).

One of the results of this study is the identification of 45 Aegilops populations of high interest due to their potential tolerance to drought and salinity, in addition to being ecogeographical gaps in the existing Spanish germplasm collections. Although predictive characterization is an inexpensive and effective approach to maximizing the likelihood of capturing a desirable level of trait expression among accessions of landraces and traditional varieties, this is the first time that predictive characterization has been applied to identifying wheat wild relatives with potential 
499

500

501

502

503

504

505

506

507

508

509

510

511

512

513

514

515

516

517

518

519

520

521

522

523

524

525

526

527

528

529

530

531

532

533

534

535

536

537

tolerance to drought and salinity. Interestingly, the validity of predictive characterization is presumably greater when used with wild relatives rather than when used with landraces, because wild relatives are more greatly affected by natural selection (no artificial selection). Thus, the link between existing environmental conditions and genotypes with local genetic adaptation is likely to be stronger than the link between environmental conditions and landraces or modern varieties, which is explored by FIGS.

In spite of having different geographic distributions, all studied Aegilops species occur in a variety of soil bedrock types (although predominantly in limestone), have a considerable precipitation range and are largely autogamous. The latter implies that genetic diversity is likely to be small within populations while local adaptation can generate large genetic differentiation among populations subject to different environmental conditions. Priority ecogeographical gaps of Aegilops that occur in sites where the Lang aridity index is $<40$ (Fig. 5a) show a good representation of all five species, including Ae. neglecta and Ae. triuncialis, which can also been found in habitats more humid than those found in the other three species. The selection for the highest topsoil salinity values (Fig. 5b) generated a more heterogenous representation of the five species. Although Ae. ventricosa is the only species explicitly characterized in saline locations, just two populations of this species where selected in the PC subset for salinity tolerance. On the other hand, Ae. geniculata and Ae. neglecta, were the most represented in this subset (47 and $33 \%$, respectively). This is largely explained by their large distribution area and great number of recorded populations. This implies that both species with more narrowly specialized habitats and those with larger distribution and wider ecological range can positively contribute genetic adaptations to particular environmental conditions.

Until now, the search for tolerance to drought and salinity in wheat has been carried out using approaches such as those in Colmer et al. (2006); Molnár et al. (2004); Farooq (2002); and Xing et al. (1993). FIGS approaches in cultivated wheat have focused on resistance to biotic factors such as plagues and diseases (Endresen et al., 2011, 2012; El Bouhssini et al., 2009, 2011; Bhullar et al., 2009). Nevertheless, in other crops FIGS has been successfully applied in the search for abiotic stress tolerance. For example, Khazaei et al. (2013) tested the effectiveness of FIGS to search for traits related to drought adaptation in a large faba bean (Vicia faba L.) collection.

According to predictive characterization methods (Thormann et al., 2016), the probability of capturing phenotypes tolerant to drought and salinity in the predictive characterization subset would be higher than in a randomly chosen set. The 45 priority populations identified by the predictive characterization approach in this study are now considered priority collection populations for further optimized collecting activities of Aegilops germplasm. They will be shortly looked for and collected for ex situ conservation. When planning the collecting mission, the combined skills of a good field botanist, genetic resources expert and ecologist taking part in the collecting team should be used to critically assess the predictions obtained with this analysis and make further predictions for sites with potentially salt and drought tolerant germplasm. 
538 Quality limitations of currently available species distribution and ecogeographic data may

539 generate priority collection sites where the species no longer exist or the estimated

540 ecogeographic conditions do not actually take place. Therefore, it is essential that the aridity and

541 topsoil salinity conditions are verified at the site at the same time seeds are collected in the

542 population. Then, the collected populations will be assessed for their tolerance to drought and

543 salinity in order to validate the methodology.

\section{Conclusions}

545 This study aimed to identify spatial and ecogeographical gaps in the Spanish germplasm

546 collection of Aegilops and priority populations of potential interest due to their possible tolerance

547 to drought and salinity. The methodology employed allowed us to establish an optimized

548 collecting strategy by filtering potential collecting sites, thereby avoiding over-representation

549 and identifying populations from low and non-represented ecogeographical categories. It also

550 provided a subset of 45 populations of potential interest in terms of tolerance to drought and

551 salinity. Because current knowledge of the real distribution of this species is still incomplete, this

552 methodological approach should be observed in dynamic terms. As the quantity and quality of

553 species distribution data improves, this type of study should be carried out again and the

554 collection priorities should be updated accordingly.

555 Subsequent collections and evaluations of these populations will provide essential feedback on

556 the efficacy of these approaches to improving the genetic representativity of genebank

557 collections and identify genotypes with desired traits.

558

559 Acknowledgments

560 We would like to thank the personnel at CRF-INIA. We are also grateful to Lori De Hond for her 561 linguistic assistance.

562

563

\section{$\underline{\text { References }}$}

- $\quad$ Abrol IP, Yadav JSP, Massoud FI. 1988. Salt-affected soils and their management. FAO

565

566 Soils Bulletin 39, FAO, Rome. Available at http://www.fao.org/docrep/x5871e/x5871e03.htm (accessed 06 June 2016).

- $\quad$ Al-maskri A, Hameed M, Ashraf M, Khan M, Fatima S, Nawaz T, Batool R. 2014. Structural features of some wheat (Triticum spp.) landraces/cultivars under drought and salt stress. Arid Land Research and Management 28:355-370.

- Araus JL, Slafer GA, Reynolds MP, Royo C. 2002. Plant breeding and drought in $\mathrm{C}_{3}$ cereals: what should we breed for? Annals of Botany 89:925-940. 
572 - $\quad$ Arrigo N, Guadagnuolo R, Lappe S, Pasche S, Parisod C, Felber F. 2011. Gene flow between wheat and wild relatives: empirical evidence from Aegilops geniculata, Ae. neglecta and Ae. triuncialis. Evolutionary Applications. DOI:10.1111/j.17524571.2011.00191.x

576

- Bari A, Amri, A Street K, Mackay M, De Pauw E, Sanders R, Nazari K, Humeid B,

577 Konopka J, Alo F. 2014. Predicting resistance to stripe (yellow) rust (Puccinia striiformis) in wheat genetic resources using focused identification of germplasm strategy. Journal of Agricultural Science 152:906-916.

- $\quad$ Bari A, Street K, Mackay M, Endresen DTF, De Pauw E, Amri A. 2011. Focused identification of germplasm strategu (FIGS) detects wheat stem rust resistance linked to environmental variables. Genetic Resources and Crop Evolution. doi:10.1007/s10722011-9775-5.

- $\quad$ Bhullar NK, Street K, Mackay M, Yahiaoui N, Keller B. 2009. Unlocking wheat genetic resources for the molecular identification of previously undescribed functional alleles at the Pm3 resistance locus. Proceedings of the National Academy of Sciences 106:95199524.

- Castañeda-Álvares NP, de Haan S, Juárez H, Khoury CK, Achicanoy HA, Sosa CC, Vernay V, Salas A, Heider B, Simon R, Maxted N, Spooner DM. 2015. Ex situ conservation priorities for the wild relatives of potato (Solanum L. section petota). Plos One. doi:101371/journalpone0122599.

- Colmer TD, Flowers TJ, Munns R. 2006. Use of wild relatives to improve salt tolerance in wheat. Journal of Experimental Botany 57 (5):1059-1078.

- Cutler DR, Edwards TC, Beard KH, Cutler A, Hess KT, Gibson J, Lawler JJ. 2007. Random Forests for classification in ecology. Ecology 88 (11):2783-2792.

- El Bouhssini M, Street K, Amri A, Mackay M, Ogbonnaya FC, Omran A, Abdalla O, Baum M, Dabbous A, Rihawi F. 2011. Sources of resistance in bread wheat to Russian wheat aphid (Diuraphis noxia) in Syria identified using the Focused Identification of Germplasm Strategy (FIGS). Plant Breeding 130:96-97.

- $\quad$ El Bouhssini M, Street K, Joubi A, Ibrahim Z, Rihawi F. 2009. Sources of wheat resistance to Sunn pest, Eurygaster integriceps Puton, in Syria. Genetic Resources and Crop Evolution 56:1065-1069.

- $\quad$ Endresen DTF, Street K, Mackay M, Bari A, Amri A, De Pauw E, Nazari K, Yahyaoui A. 2012. Sources of resistance to stem rust (Ug99) in bread wheat and durum wheat identified using focused identification of germplasm strategy. Crop Science 52:764-773.

- Endresen DTP. 2011. Predictive association between biotic stress traits and ecogeographic data for wheat and barley landraces. Crops Science 51:2036-2055.

- FAO/Bioversity Multi-crop Passport Descriptors V.2. 2012. Available at http://www.bioversityinternational.org/fileadmin/user_upload/online_library/publications /pdfs/FAO-Bioversity_multi_crop_passport_descriptors_V_2_Final_rev_1526.pdf (accessed 30 June 2016).

- FAO. 2013a. FAOSTAT. Available at http://faostat3.fao.org/home/E (07 January 2016).

- FAO. 2013b. Drought. Available at http://www.fao.org/docrep/017/aq191e/aq191e.pdf (accessed 07 January 2016). 
615 - Farroq S. 2002. A. ovata: a potential gene source for improvement of salt tolerance of

616 wheat. In: Ahmad R, Malik KA, ed. Prospects for saline agriculture, vol 37. Dordrecht:

$617 \quad$ Kluwer Academic Publishers, 123-130.

618 - Fielder H, Brotherton P, Hosking J, Hopkins JJ, Ford-Lloyd B, Maxted N. 2015.

619 Enhancing the conservation of crop wild relatives in England. PLoS ONE 10(6):

$620 \quad \mathrm{e} 0130804$. doi:10.1371/journal.pone.0130804.

621 - Fielder H, Sith C, Ford-Lloyd B, Maxted N. 2016. Enhancing the conservation of crop

622 wild relatives in Scotland. Journal for Nature Conservation 29:51-61.

623 - Fita A, Rodríguez-Burruezo A, Boscaiu M, Prohens J, Vicente O. 2015. Breeding and domesticating crops adapted to drought and salinity: a new paradigm for increasing food production. Frontiers in Plant Science volumen 6 article 978.

626

627

- Glick BR, Cheng Z, Czarny J, Duan J. 2007. Promotion of plant growth by ACC

628 deaminase-producing soil bacteria. European Journal of Plant Pathology 119:329-339.

629

630

631

- Graham CH, Elith J, Hijmans RJ, Guisan A, Peterson AT, Loisells BA, The Nceas Predicting Species Distributions Working Group. 2008. Journal of Applied Ecology 45:239-247.

- Hameed M, Ashraf M, Naz N. 2011. Anatomical and physiological characteristics relating to ionic relations in some salt tolerant grasses from the Salt Range. Pakistan Acta Physiologiae Plantarum 33:1399-1409.

- Hammer K. 1980. Vorarbeiten zur Monographischen Darstellung von Wildpflanzensortimenten: Aegilops L. Kulturpflanze 28:33-180.

- Harmonized world soil (HWS) Database (version 12). 2012. Available at http://webarchive.iiasa.ac.at/Research/LUC/External-World-soil-database/HTML/. FAO, Rome, Italy and IIASA, Laxenburg, Austria (accessed 1 April 2013).

- Heywood V, Casas A, Ford-Lloyd B, Kell S, Maxted N. 2007. Conservation and sustainable use of crop wild relatives. Agriculture, Ecosystems and Environment 121: 245-255.

- Hijmans RJ, Cameron SE, Parra JL, Jones PG, Jarvis A. 2005. Very high resolution interpolated climate surfaces for global land areas International Journal of Climatology 25:1965-1978 (http://www.worldclim.org).

- Iriondo JM, Albert MJ, Giménez L, Domínguez F, Escudero A. 2009. Poblaciones en peligro: viabilidad demográfica de la flora vascular amenazada de España. Dirección General de Medio Natural y Política Forestal (Ministerio de Medio Ambiente, y Medio Rural y Marino), Madrid.

650

651

652

653

654

655

- Jarvis A, Reuter HI, Nelson A, Guevara E. 2008. Digital Elevation Models (DEM) of the Shuttle Radar Topography Mission (SRTM). Hole-filled SRTM for the globe Version 4. Available from the CGIAR-CSI SRTM 90m Database at http://srtm.csi.cgiar.org/ (accessed 07 January 2016).

- Ketchen DJ, Shook CL. 1996. The application of cluster analysis in strategic management research: an analysis and critique. Strategic Management Journal 17 (6):441-458. 
656 - Khazaei H, Strett K, Bari A, Mackay M, Stoddard F. 2013. The FIGS (Focused Identification of Germplasm Strategy (FIGS) approach identifies traits related to drought adaptation in Vicia faba genetic resources. Plos One, October, Volume 8, Issue 3.

- Khoury CK, Castañeda-Álvarez NP, Achicanoy HS, Sosa CC, Bernau V, Kassa MT, Norton SL, van der Maesen JG, Upadhyaya HD, Ramírez-Villegas J, Jarvis A, Struik PC. 2015. Crop wild relatives of pigeonpea (Cajanus cajan (L.) Millsp.): distributions, ex situ conservation status, and potential genetic resources for abiotic stress tolerance. Biological Conservation 184:259-270.

- Khoury C, Laliberté B, Guarino L. 2010. Trends in ex situ conservation of plant genetic resources: a review of global crop and regional conservation strategies. Genetic Resources and Crop Evolution 57: 625-639.

- Lambers H, Chapin FS, Pons TL. 2008. Plant Physiological Ecology, $2^{\text {nd }}$ Ed. Springer, New York.

- Mackay MC, Street K. 2004. Focused identification of germplasm strategy - FIGS. In: Black CK, Panozzo JF, Rebetzke GJ, ed. Cereals 2004, Proceedings of the $54^{\text {th }}$ Australian Cereal Chemistry Conference and the $11^{\text {th }}$ Wheat Breeders' Assembly Cereal Chemistry Division. Royal Australian Chemical Institute, Melbourne, 138-141.

- Maldonado C, Molina CI, Zizka A, Persson C, Taylor CM, Albán J, Chilquillo E, Ronsted N, Antonelli A. 2015. Estimating species diversity and distribution in the era of Big Data: to what extent can we trust public databases? Global Ecology and Biogeography. doi:101111/geb12326.

- Maxted N, White K, Valkoun J, Konopka J, Hargreaves S. 2008. Towards a conservation strategy for Aegilops species. Plant Genetic Resources: Characterization and Utilization 6 (2):126-141.

- Mólnar I, Gáspár L Sárvári E, Dulai S, Hoffmann B, Molnár-Láng M, Galiba G. 2004. Physiological and morphological responses to water stress in Aegilops biuncialis and Triticum aestivum genotypes with differing tolerance to drought. Functional Plan Biology 31:1149-1159.

- Mondini L, Nachit MM, Pagnotta MA. 2015. Allelic variants in durum wheat (Triticum turgidum L. var. durum) DREB genes conferring tolerance to abiotic stresses. Molecular Genetics and Genomics 290:531-544.

- Mujeeb-Kazi A, Diaz de Leon JL. 2002. Conventional and alien genetic diversity for salt tolerant wheats: focus on current status and new germplasm development. In: Ahmad R, Malik KA, ed. Prospects for saline agriculture 37. Dordrecht: Kluwer Academic Publishers, 69-82.

- Noorka IR, Pat Heslop-Harrison JS. 2014. Water and Crops: Molecular biologists, physiologists, and plant breeders approach in the context of evergreen revolution. In: Taylor, F, ed. Hand book of Plant and Crop Physiology. CRC Press, 967-978.

- Parra-Quijano M, Torres E, Iriondo JM, López F. 2015. CAPFITOGEN Tools. User Manual version 2.0. International Treaty on Plant Genetic Resources for Food and Agriculture, FAO, Rome. 
697 - Parra-Quijano M, Iriondo JM, Torres E. 2012a. Ecogeographical land characterization 698 maps as a tool for assessing plant adaptation and their implications in agrobiodiversity studies. Genetic Resources and Crop Evolution 59:205-217.

701

- Parra-Quijano M, Iriondo JM, Torres ME. 2012b. Improving representativeness of genebank collections through species distribution models, gap analysis and

703 ecogeographical maps. Biodiversity and Conservation 21:79-96.

704

- Parra-Quijano M, Draper D, Torres E, Iriondo JM. 2008. Ecogeographical

705

706 representativeness in crop wild relative ex-situ collections. In: Maxted N, Ford-Lloyd

707

708

709

710

711

712

713

714

715

716

717

718

719 BV, Kell SP, Iriondo JM, Dullo ME, Turok J, ed. Crop wild relative conservation and use. CAB International, Wallingford, 249-273.

- Ramírez-Villegas J, Khoury C, Javis A, Debouck DG, Guarino L. 2010. A gap analysis methodology for collecting crop genepools: a case study with Phaseolus beans. PLoS ONE 5(10): e13497. doi:10.1371/journal.pone.0013497.

- Rubio Teso ML, Iriondo JM, Parra-Quijano M, Torres E. 2013. National Strategy for the Conservation of Crop Wild Relatives of Spain PGR Secure. Available at http://www.pgrsecure.bham.ac.uk/sites/default/files/documents/public/National_CWR_C onservation_Strategy_Spain.pdf(accessed 30 June 2016).

- Shehadeh A, Amri A, Maxted N. 2014. Ecogeographic survey and gap analysis of Lathyrus L. species. Genetic Resources and Crop Evolution 60:2101-2113.

- Thormann I, Parra-Quijano M, Rubio Teso ML, Endresen DTF, Dias S, Iriondo JM, Maxted N. 2016. Predictive characterization methods for accessing and using CWR diversity. In: Maxted N, Dulloo ME, Ford-Lloyd BV, ed. Capturing wild relative and landrace diversity for crop improvement, 64-77.

- Tóth G, Montanarella L, Rusco E. 2008. Updated map of salt affected soils in the European Union. In: Tóth G, Montanarella L, Rusco E, ed. Threats to soil quality in Europe. EUR 23438 - Scientific and Technical Research series Luxembourg: Office for Official Publications of the European Communities, 61-74.

- Van Slageren MW. 1994. Wild wheats: A monograph of Aegilops L. and Amblyopyrum (Jaub. \& Spach) Eig. Wageningen Agricultural University, Veenman Drukkers, Wageningen. The Nehterlands.

- Xing X, Monneveux P, Damania AB, Zarahieva M. 1993. FAO/IPGRI Plant Genetic Resources Newsletter 96:11-1. 
Figure 1

Process carried out to identify ecogeographical gaps in the Spanish Aegilops germplasm collections with potential tolerance to drought and salinity.

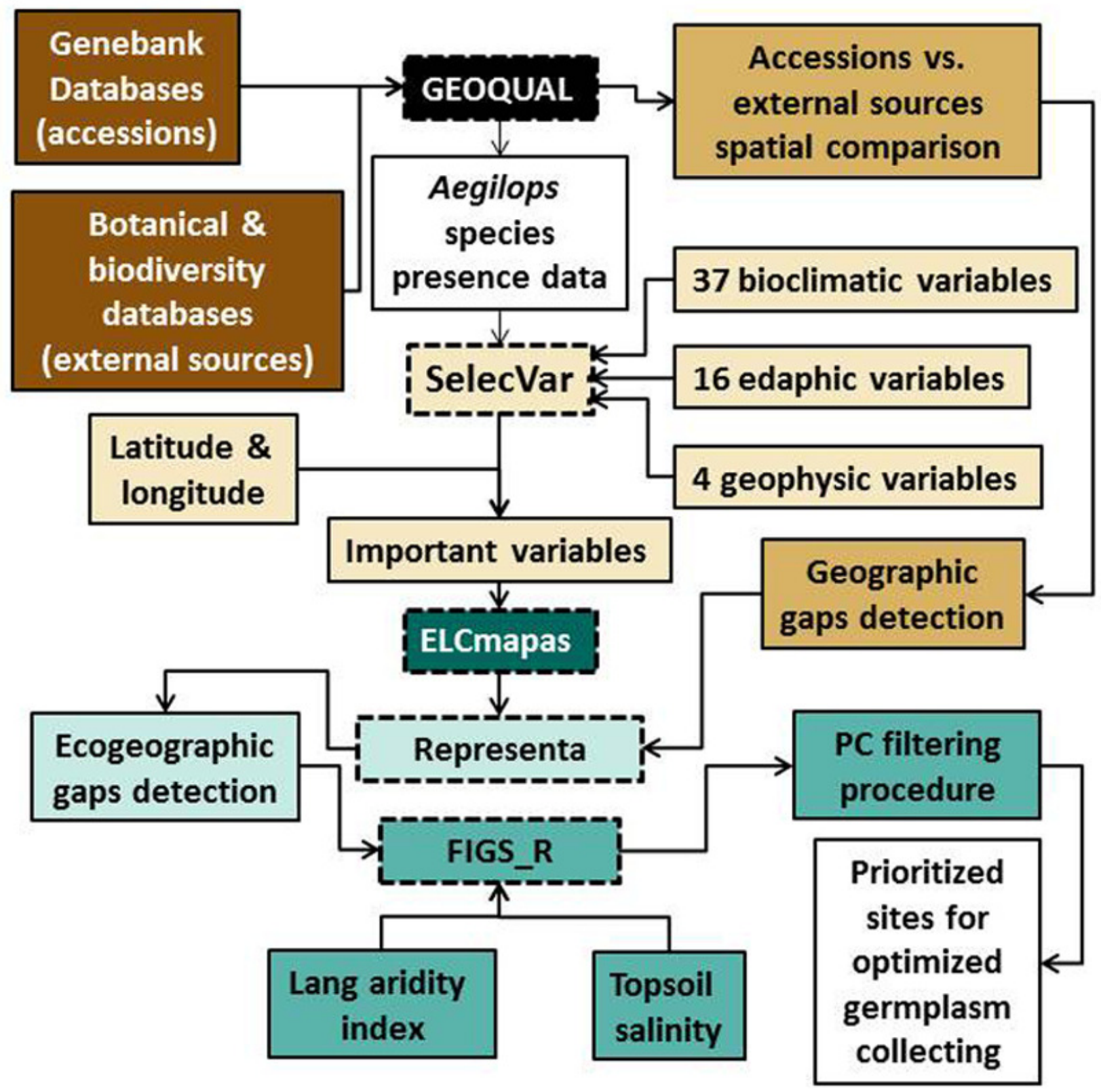


Figure 2

Location of (a) origin of germplasm accessions in Peninsular Spain, the Balearic Islands and the Canary Islands and (b) population occurrence from external sources of $A e$. geniculata. 


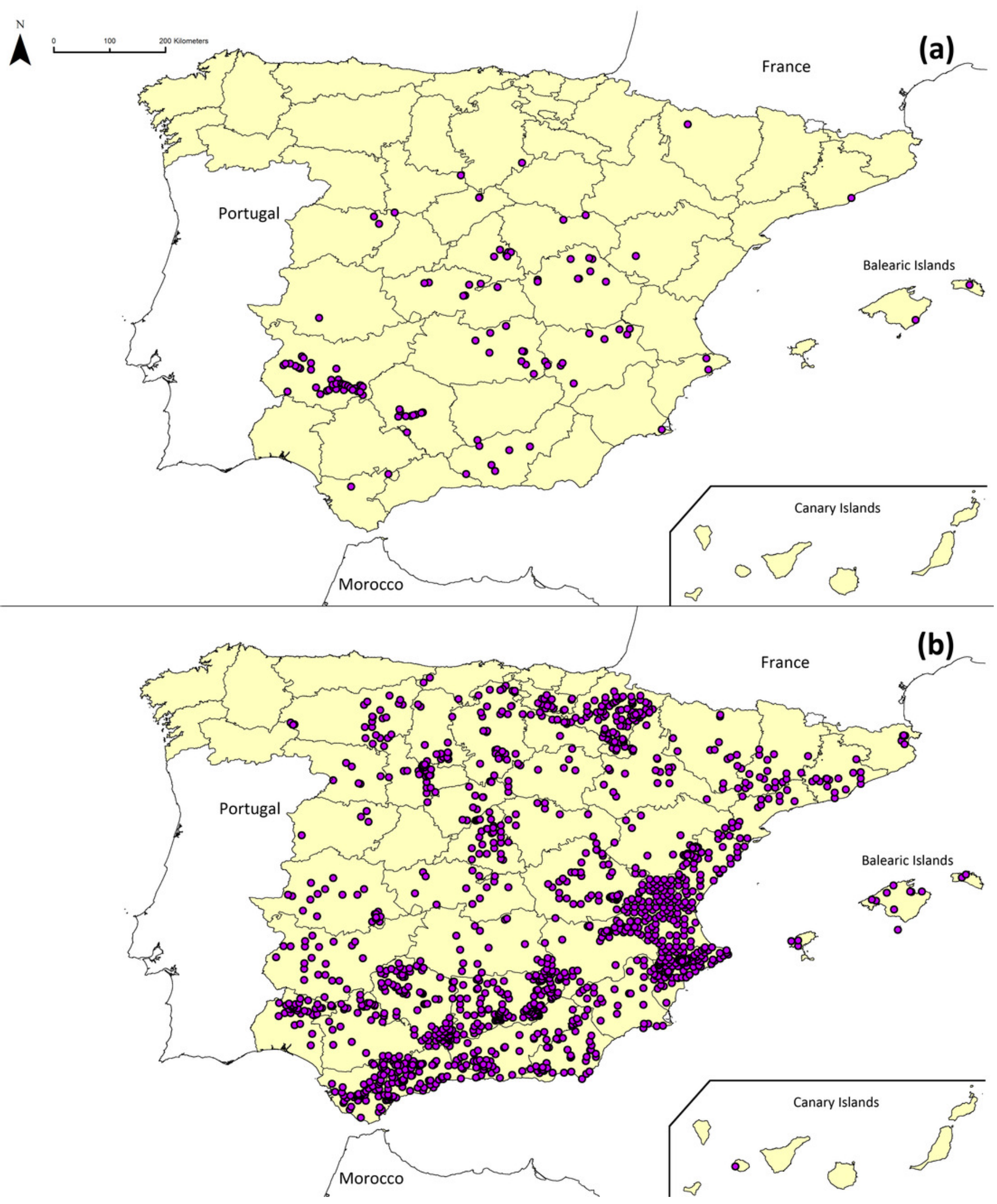


Figure 3

ELC map of Ae. geniculata for Peninsular Spain, the Balearic Islands and the Canary Islands. The environmental characteristics of the different categories are described in Table S10.

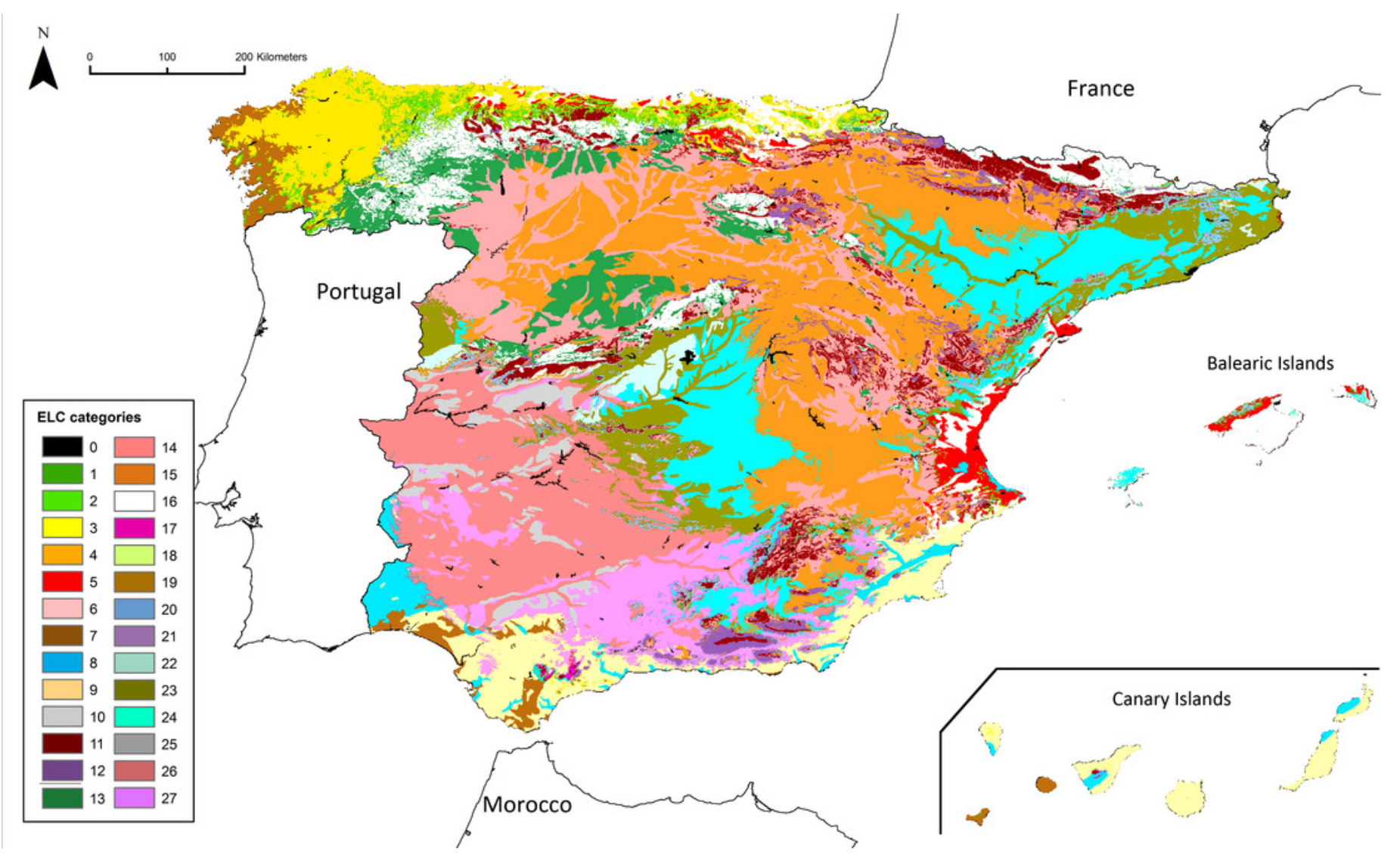


Figure 4

Location of the Ae. geniculata populations identified as priority ecogeographical gaps in Spain.

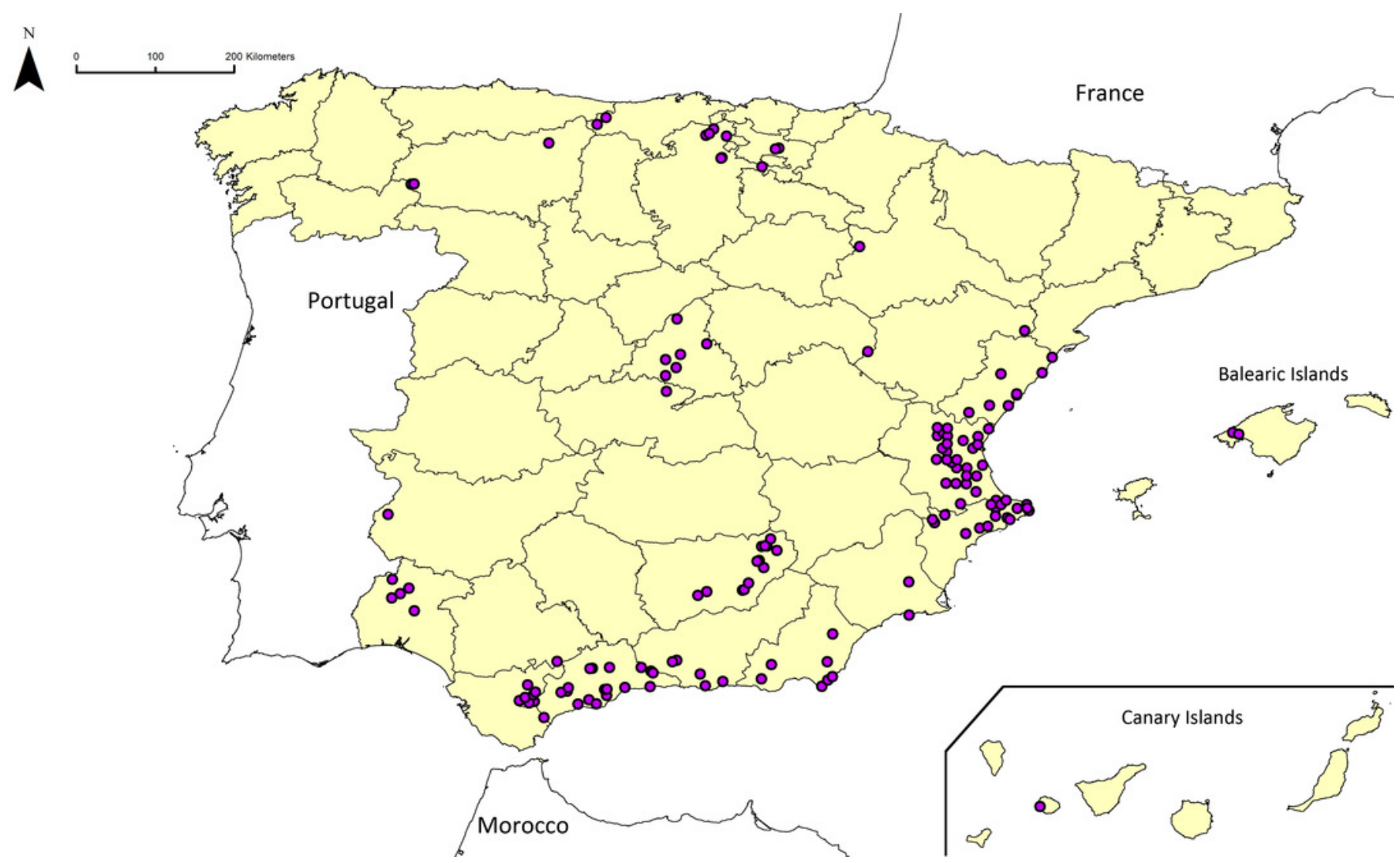




\section{Figure 5}

Location of (a) priority ecogeographical gaps (PEG) of Aegilops in Spain that occur in sites where $\mathrm{Al}_{\mathrm{L}}<40$, and (b) PEG that occur in sites where the highest salinity values are also found. 


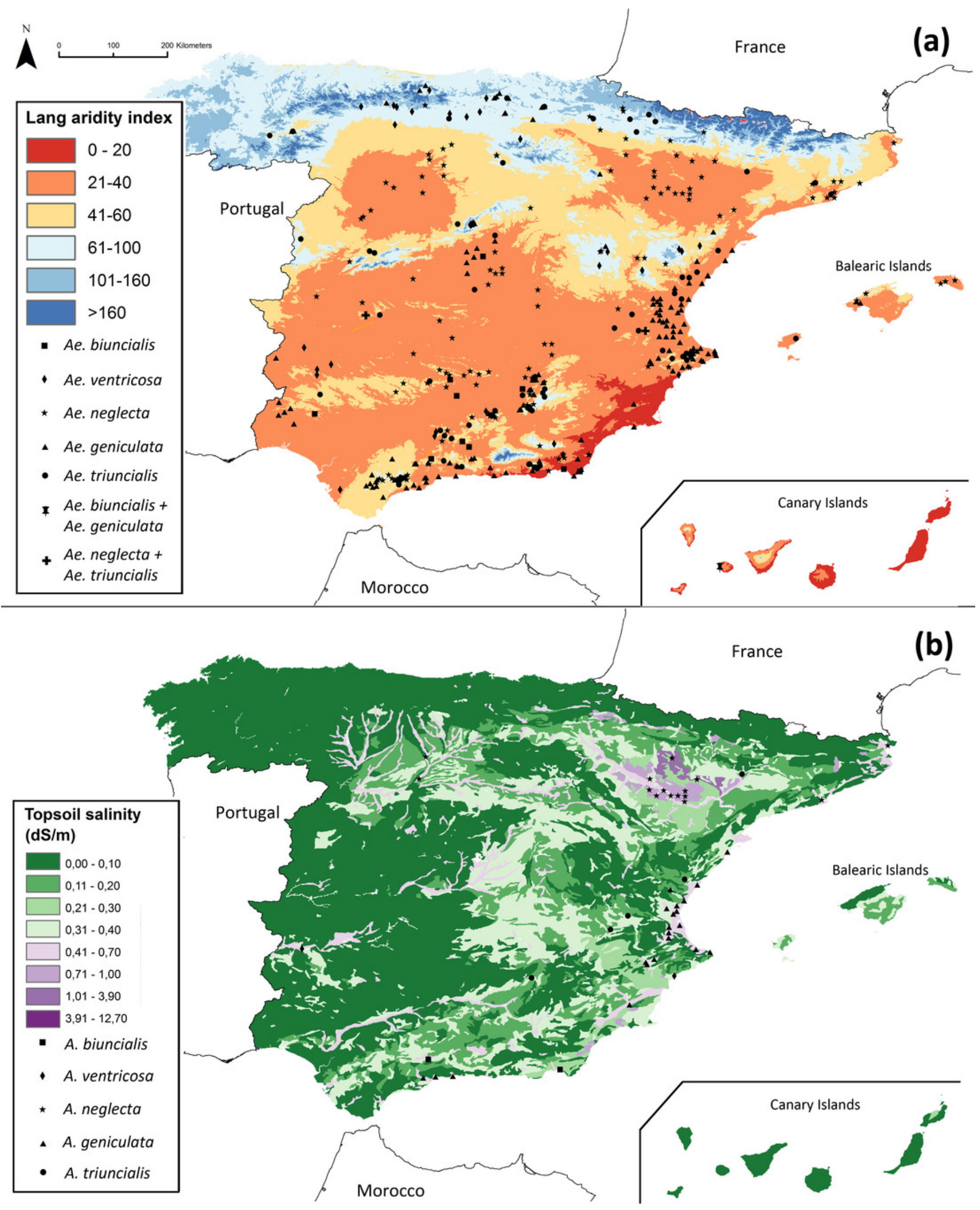




\section{Table $\mathbf{1}$ (on next page)}

Autecology and mating system of the targeted Aegilops species. Information obtained from Van Slageren (1994) unless otherwise stated. 


\begin{tabular}{|c|c|c|c|c|c|}
\hline & Ae.biuncialis & Ae. geniculata & Ae. neglecta & Ae. triuncialis & Ae. ventricosa \\
\hline $\begin{array}{l}\text { General } \\
\text { habitat }\end{array}$ & \multicolumn{5}{|c|}{ Dry and disturbed habitats (fallow, roadsides, edges of cultivation). } \\
\hline $\begin{array}{l}\text { Specific } \\
\text { habitat }\end{array}$ & $\begin{array}{l}\text { Dry, rocky mountain } \\
\text { slopes. }\end{array}$ & $\begin{array}{l}\text { Dry, rocky mountain } \\
\text { slopes, wastelands. }\end{array}$ & $\begin{array}{l}\text { Stony fields and hill } \\
\text { slopes. Marginal } \\
\text { habitats where parent } \\
\text { rock surfaces } \\
\text { and only pockets of } \\
\text { the top soil remain. }\end{array}$ & $\begin{array}{l}\text { Wastelands, sandy } \\
\text { wadis (dry } \\
\text { riverbeds), and dry } \\
\text { rocky slopes of hills } \\
\text { and mountains. }\end{array}$ & $\begin{array}{l}\text { Sandy wadis, } \\
\text { including saline } \\
\text { locations, and even } \\
\text { marshy riversides. }\end{array}$ \\
\hline Vegetation & $\begin{array}{l}\text { Various forest } \\
\text { types (frequently with } \\
\text { Pinus halepensis and } \\
\text { Quercus sp.). Also in } \\
\text { grasslands, } \\
\text { maquis vegetation and } \\
\text { steppe. More } \\
\text { rarely in river valleys. }\end{array}$ & $\begin{array}{l}\text { Vegetation types } \\
\text { include garrigue, } \\
\text { maquis, grassland, } \\
\text { shrub, woodlands, } \\
\text { forests and } \\
\text { scrubs (e.g., of } \\
\text { Quercus, Pinus, } \\
\text { Juniperus and } \\
\text { Pistacia). Steppe, and, } \\
\text { more rarely, also } \\
\text { humid pastures, dunes } \\
\text { and even swamps. }\end{array}$ & $\begin{array}{l}\text { Vegetation types } \\
\text { such as, grasslands, } \\
\text { stony fields and } \\
\text { hillslopes, maquis, } \\
\text { garrigue, } \\
\text { in forests or scrubs of } \\
\text { e.g., Acacia, Quercus, } \\
\text { Ceratonia and Pinus. } \\
\text { Occasionally found on } \\
\text { river banks and } \\
\text { generally more } \\
\text { humid habitats. }\end{array}$ & $\begin{array}{l}\text { Vegetation types } \\
\text { include garrigue, } \\
\text { maquis, grassland, } \\
\text { shrub- and woodlands, } \\
\text { (open) forests and } \\
\text { scrubs, e.g., of Acacia, } \\
\text { Quercus, Pinus, } \\
\text { Juniperus, and of } \\
\text { cultivated Pistacia, } \\
\text { Ceratonia siliqua and } \\
\text { Liquidambar trees. } \\
\text { Also found } \\
\text { in the steppe up to the } \\
\text { margin of the desert, } \\
\text { but, more rarely, also } \\
\text { in humid pastures, } \\
\text { river terraces. }\end{array}$ & $\begin{array}{l}\text { Grasslands. } \\
\text { Also found in scrubs } \\
\text { of Pistacia and } \\
\text { Juniperus, } \\
\text { oak forests, and in } \\
\text { Poterium-dominated } \\
\text { vegetation. }\end{array}$ \\
\hline Soil & $\begin{array}{l}\text { Variety of bedrock } \\
\text { types: mainly } \\
\text { limestone but also on } \\
\text { schists, shales, basalt, } \\
\text { granite, and pillow } \\
\text { lavas. } \\
\text { Soil textures are } \\
\text { mainly clay- or sandy } \\
\text { loam, or clay, or } \\
\text { (rarely) pure sandy } \\
\text { soils. }\end{array}$ & $\begin{array}{l}\text { Bedrock is } \\
\text { predominantly } \\
\text { limestone } \\
\text { but shales, pillow } \\
\text { lava, silicate, } \\
\text { Mediterranean terra } \\
\text { rosa, karst, basalt and } \\
\text { sandstone } \\
\text { are also reported. } \\
\text { Soil texture also varies } \\
\text { widely: often on clay- } \\
\text { and sandy } \\
\text { loam, clay, and gravel; } \\
\text { more rarely on pure }\end{array}$ & $\begin{array}{l}\text { The parent rock is } \\
\text { mainly limestone, but } \\
\text { less frequently also } \\
\text { alluvium, } \\
\text { basalt, pillow lava, } \\
\text { schists, silicates, and } \\
\text { sandstone } \\
\text { Recorded soil textures } \\
\text { include loam, } \\
\text { clayloam, sandy loam, } \\
\text { and, more rarely, } \\
\text { sands and clay. }\end{array}$ & $\begin{array}{l}\text { Bedrock is } \\
\text { predominantly } \\
\text { limestone and basalt, } \\
\text { but shales, pillow } \\
\text { lava, silicate, } \\
\text { Mediterranean terra } \\
\text { rosa, karst, schist, and } \\
\text { sandstone are also } \\
\text { reported. } \\
\text { Soil texture } \\
\text { varies widely; often } \\
\text { on clay- and sandy } \\
\text { loam, (sandy) clay, } \\
\text { and gravel; more }\end{array}$ & $\begin{array}{l}\text { Predominantly on } \\
\text { soils with a limestone } \\
\text { bedrock, far less on } \\
\text { basalt or sandstone. } \\
\text { Recorded soil textures } \\
\text { include clay- and } \\
\text { sandy loams, less } \\
\text { often more pure clay } \\
\text { or } \\
\text { loam. Growth on very } \\
\text { poor, stony soils. }\end{array}$ \\
\hline
\end{tabular}




\begin{tabular}{|l|l|l|l|l|l|}
\hline & & $\begin{array}{l}\text { sand and highly } \\
\text { organic soil such as } \\
\text { turf. }\end{array}$ & $\begin{array}{l}\text { rarely on loss, pure } \\
\text { sands, and marly soils. }\end{array}$ & \\
\hline Climate & $\begin{array}{l}\text { Annual rainfall data of } \\
225-800 \mathrm{~mm} \text { indicate } \\
\text { some drought } \\
\text { tolerance, but it also } \\
\text { occurs in areas with as } \\
\text { much as 1250 } \\
\text { mm. }\end{array}$ & $\begin{array}{l}\text { Wide annual rainfall } \\
\text { amplitude, varying } \\
\text { from less than } 100 \\
\text { mm up to } \\
1100 \mathrm{~mm} .\end{array}$ & $\begin{array}{l}\text { Rainfall data vary } \\
\text { from } 450 \text { to } 750 \mathrm{~mm}, \\
\text { and in some sites it } \\
\text { can be } \\
\text { as high as } 1400 \mathrm{~mm} .\end{array}$ & $\begin{array}{l}\text { Wide annual rainfall } \\
\text { amplitude, varying } \\
\text { from 125 mm } \\
\text { up to } 1400 \mathrm{~mm} .\end{array}$ & $\begin{array}{l}\text { Rainfall data vary } \\
\text { widely: from less than } \\
100 \mathrm{~mm} \text { up to } \\
600 \mathrm{~mm}, \text { but most are } \\
\text { from the range 200- } \\
350 \mathrm{~mm} .\end{array}$ \\
\hline $\begin{array}{l}\text { Mating } \\
\text { system }\end{array}$ & $\begin{array}{l}\text { Considered largely } \\
\text { autogamous (Hammer, } \\
1980)\end{array}$ & $\begin{array}{l}\text { Considered largely } \\
\text { autogamous (Hammer, } \\
1980) \text { but mixed } \\
\text { mating has been } \\
\text { observed (Arrigo et } \\
\text { al., 2011). }\end{array}$ & $\begin{array}{l}\text { Considered largely } \\
\text { autogamous (Hammer, } \\
1980) \text { but mixed } \\
\text { mating has been } \\
\text { observed (Arrigo et } \\
\text { al., 2011). }\end{array}$ & $\begin{array}{l}\text { Considered largely } \\
\text { autogamous (Hammer, } \\
1980) \text { but mixed } \\
\text { mating has been } \\
\text { observed (Arrigo et } \\
\text { al., 2011). }\end{array}$ & $\begin{array}{l}\text { Considered largely } \\
\text { autogamous (Hammer, } \\
1980) \text { but it can } \\
\text { occasionally } \\
\text { hybridize with wheat } \\
\text { (Van Slageren, 1994). }\end{array}$ \\
\hline
\end{tabular}

2 


\section{Table 2 (on next page)}

Number of Aegilops accessions and external sources with coordinates included in the study before and after clearing spatial duplicates and filtering by the geo-referencing quality threshold. 


\begin{tabular}{|c|c|c|c|c|c|c|c|c|c|c|}
\hline & \multicolumn{2}{|c|}{ Ae. biuncialis } & \multicolumn{2}{|c|}{ Ae. geniculata } & \multicolumn{2}{|c|}{ Ae. neglecta } & \multicolumn{2}{|c|}{ Ae.triuncialis } & \multicolumn{2}{|c|}{ Ae. ventricosa } \\
\hline & $\begin{array}{l}\text { Germplasm } \\
\text { accesions }\end{array}$ & $\begin{array}{l}\text { Occurrence } \\
\text { records } \\
\text { from } \\
\text { external } \\
\text { sources } \\
\end{array}$ & $\begin{array}{l}\text { Germplasm } \\
\text { accesions }\end{array}$ & $\begin{array}{l}\text { Occurrence } \\
\text { records } \\
\text { from } \\
\text { external } \\
\text { sources }\end{array}$ & $\begin{array}{l}\text { Germplasm } \\
\text { accesions }\end{array}$ & $\begin{array}{l}\text { Occurrence } \\
\text { records } \\
\text { from } \\
\text { external } \\
\text { sources }\end{array}$ & $\begin{array}{l}\text { Germplasm } \\
\text { accesions }\end{array}$ & $\begin{array}{l}\text { Occurrence } \\
\text { records } \\
\text { from } \\
\text { external } \\
\text { sources }\end{array}$ & $\begin{array}{l}\text { Germplasm } \\
\text { accesions }\end{array}$ & $\begin{array}{l}\text { Occurrence } \\
\text { records } \\
\text { from } \\
\text { external } \\
\text { sources }\end{array}$ \\
\hline $\begin{array}{l}\text { Initial } \\
\text { number of } \\
\text { georeferenc } \\
\text { ed records }\end{array}$ & 6 & 30 & 144 & 4850 & 33 & 870 & 191 & 1674 & 26 & 363 \\
\hline $\begin{array}{l}\text { Number of } \\
\text { records } \\
\text { removed for } \\
\text { having low } \\
\text { accuracy* }\end{array}$ & $0(0 \%)$ & $13(43 \%)$ & $0(0 \%)$ & $1292(27 \%)$ & $0(0 \%)$ & $372(43 \%)$ & $0(0 \%)$ & $580(35 \%)$ & $0(0 \%)$ & $99(27 \%)$ \\
\hline $\begin{array}{l}\text { Number of } \\
\text { records } \\
\text { removed for } \\
\text { been } \\
\text { considered } \\
\text { spatial } \\
\text { duplicates }\end{array}$ & $0(0 \%)$ & $1(3 \%)$ & $20(14 \%)$ & $1879(39 \%)$ & $1(3 \%)$ & $71(8 \%)$ & $12(6 \%)$ & $221(13 \%)$ & $2(8 \%)$ & $63(17 \%)$ \\
\hline $\begin{array}{l}\text { Number of } \\
\text { non- } \\
\text { duplicated } \\
\text { records with } \\
\text { TOTALQU } \\
\text { AL } \leq 80\end{array}$ & $2(33 \%)$ & $1(3 \%)$ & $5(3 \%)$ & $317(7 \%)$ & $3(9 \%)$ & $73(8 \%)$ & $5(3 \%)$ & $148(9 \%)$ & $5(19 \%)$ & $43(12 \%)$ \\
\hline $\begin{array}{l}\text { Number of } \\
\text { non- } \\
\text { duplicated } \\
\text { records with } \\
\text { TOTALQU } \\
\text { AL }>80\end{array}$ & $4(67 \%)$ & $15(50 \%)$ & $119(83 \%)$ & $1362(28 \%)$ & $29(88 \%)$ & $354(41 \%)$ & $174(91 \%)$ & $725(43 \%)$ & $19(73 \%)$ & $158(44 \%)$ \\
\hline
\end{tabular}


4 *Number of records with geographic coordinates expressed in decimal degrees with less than two decimals in both latitude and

5 longitude or without textual information on the occurrence site, plus records with geographic coordinates expressed in UTM with 6 lower resolution than $1 \times 1 \mathrm{~km}$. 


\section{Table 3 (on next page)}

Variables selected in each Aegilops species and ecogeographical component according to the importance function of the random forest approach (see Table S1 for variable description). 


\begin{tabular}{|c|l|l|l|}
\hline \multicolumn{1}{|c|}{ Species } & \multicolumn{1}{|c|}{$\begin{array}{c}\text { Bioclimatic } \\
\text { component }\end{array}$} & $\begin{array}{l}\text { Geophysic } \\
\text { component }\end{array}$ & \multicolumn{1}{c|}{ Edaphic component } \\
\hline Ae. biuncialis & $\begin{array}{l}\text { 1. January minimum } \\
\text { temperature } \\
\text { 2. Precipitation of the } \\
\text { wettest month } \\
\text { 3. Isothermality }\end{array}$ & $\begin{array}{l}\text { 1. Northness } \\
\text { 2. Eastness }\end{array}$ & $\begin{array}{l}\text { 1. Topsoil salinity } \\
\text { 2. Topsoil reference bulk } \\
\text { density } \\
\text { 3. Topsoil base saturation }\end{array}$ \\
\hline Ae. geniculata & $\begin{array}{l}\text { temperature of the } \\
\text { coldest month } \\
\text { 2. Annual temperature } \\
\text { range } \\
\text { 3. Isothermality }\end{array}$ & $\begin{array}{l}\text { 1. Slope } \\
\text { 2. Altitude }\end{array}$ & $\begin{array}{l}\text { 1. Topsoil gravel content } \\
\text { 2. Topsoil organic carbon } \\
\text { 3. Topsoil sand fraction }\end{array}$ \\
\hline Ae. neglecta & $\begin{array}{l}\text { 1. March precipitation } \\
\text { 2. May maximum } \\
\text { temperature } \\
\text { 3. Isothermality }\end{array}$ & $\begin{array}{l}\text { 1. Altitude } \\
\text { 2. Northness }\end{array}$ & $\begin{array}{l}\text { 1. Topsoil total } \\
\text { exchangeable bases } \\
\text { 2. Reference depth of the } \\
\text { soil unit } \\
\text { 3. Topsoil salinity }\end{array}$ \\
\hline Ae. ventricosa & $\begin{array}{l}\text { 1. April minimum } \\
\text { temperature } \\
\text { 2. April precipitation } \\
\text { 3. Isothermality }\end{array}$ & $\begin{array}{l}\text { 1. Mean temperature } \\
\text { 2. April precipitation } \\
\text { 3. Temperature } \\
\text { seasonality }\end{array}$ & 1. Eastness \\
2. Altitude & $\begin{array}{l}\text { 1. Topsoil clay fraction } \\
\text { 2. Topsoil organic carbon } \\
\text { 3. Topsoil base saturation }\end{array}$ \\
\hline 2. Slope & $\begin{array}{l}\text { 1. Topsoil sodicity } \\
\text { 2. Topsoil reference bulk } \\
\text { density } \\
\text { 3. Topsoil base saturation }\end{array}$ \\
\hline
\end{tabular}




\section{Table 4 (on next page)}

Number of population occurrences from external sources of Aegilops subjected to representativeness analysis and number of spatial gaps and priority ecogeographical gaps identified in Spain. 
1

\begin{tabular}{|l|c|c|c|c|c|c|}
\cline { 2 - 7 } \multicolumn{1}{c|}{} & $\begin{array}{c}\text { Ae. } \\
\text { biuncialis }\end{array}$ & $\begin{array}{c}\text { Ae. } \\
\text { geniculata }\end{array}$ & $\begin{array}{c}\text { Ae. } \\
\text { neglecta }\end{array}$ & $\begin{array}{c}\text { Ae. } \\
\text { triuncialis }\end{array}$ & $\begin{array}{c}\text { Ae. } \\
\text { ventricosa }\end{array}$ & TOTAL \\
\hline $\begin{array}{l}\text { Number of } \\
\text { population } \\
\text { occurrences from } \\
\text { external sources }\end{array}$ & 15 & 1362 & 354 & 725 & 158 & 2614 \\
\hline $\begin{array}{l}\text { Number of spatial } \\
\text { gaps }\end{array}$ & 15 & 1359 & 317 & 722 & 158 & 2571 \\
\hline $\begin{array}{l}\text { Number of } \\
\text { priority } \\
\text { ecogeographical } \\
\text { gaps }\end{array}$ & 12 & 140 & 133 & 73 & 35 & 393 \\
\hline $\begin{array}{l}\text { Percentage of } \\
\text { population } \\
\text { occurrences from } \\
\text { external sources } \\
\text { identified as } \\
\text { priority } \\
\text { ecogeographical } \\
\text { gaps }\end{array}$ & 80 & 10 & 38 & 10 & 22 & - \\
\hline
\end{tabular}

2 


\section{Table 5 (on next page)}

Number of ELC categories for Aegilops currently represented in the Spanish Network and potential increase (\%) in representativeness after collecting priority ecogeographical gaps. 


\begin{tabular}{|l|c|c|c|c|c|}
\cline { 2 - 6 } \multicolumn{1}{c|}{} & $\begin{array}{c}\text { Ae. } \\
\text { biuncialis }\end{array}$ & $\begin{array}{c}\text { Ae. } \\
\text { geniculata }\end{array}$ & Ae. neglecta & $\begin{array}{c}\text { Ae. } \\
\text { triuncialis }\end{array}$ & $\begin{array}{c}\text { Ae. } \\
\text { ventricosa }\end{array}$ \\
\hline $\begin{array}{l}\text { Number of } \\
\text { categories in the } \\
\text { ELC map }\end{array}$ & 26 & 27 & 27 & 27 & 27 \\
\hline $\begin{array}{l}\text { Number of ELC } \\
\text { categories currently } \\
\text { represented in the } \\
\text { Spanish Network }\end{array}$ & 2 & 13 & 7 & 11 & 6 \\
\hline $\begin{array}{l}\text { Percentage of ELC } \\
\text { categories currently } \\
\text { represented in the } \\
\text { Spanish Network }\end{array}$ & 8 & 48 & 26 & 41 & 22 \\
\hline $\begin{array}{l}\text { Number of ELC } \\
\text { categories in the } \\
\text { spatial gaps }\end{array}$ & 9 & 26 & 26 & 22 & 18 \\
\hline $\begin{array}{l}\text { Number of ELC } \\
\text { categories in the } \\
\text { priority } \\
\text { ecogeographical } \\
\text { gaps }\end{array}$ & 7 & 12 & 19 & 11 & 12 \\
\hline $\begin{array}{l}\text { Percentage of } \\
\text { improvement in } \\
\text { ecogeographical } \\
\text { representativeness }\end{array}$ & 27 & 44 & 70 & 41 & 44 \\
\hline
\end{tabular}

2 


\section{Table 6(on next page)}

Priority ecogeographical gaps of targeted Aegilops species selected for drought and salinity tolerance in Spain. 
1

\begin{tabular}{|l|c|c|c|c|c|c|}
\cline { 2 - 7 } \multicolumn{1}{c|}{} & $\begin{array}{c}\text { Ae. } \\
\text { biuncialis }\end{array}$ & $\begin{array}{c}\text { Ae. } \\
\text { geniculata }\end{array}$ & $\begin{array}{c}\text { Ae. } \\
\text { neglecta }\end{array}$ & $\begin{array}{c}\text { Ae. } \\
\text { triuncialis }\end{array}$ & $\begin{array}{c}\text { Ae. } \\
\text { ventricosa }\end{array}$ & TOTAL \\
\hline $\begin{array}{l}\text { Priority ecogeographic } \\
\text { gaps with a Lang } \\
\text { aridity index }<40\end{array}$ & 10 & 103 & 76 & 26 & 8 & 223 \\
\hline $\begin{array}{l}\text { Priority ecogeographic } \\
\text { gaps with a Lang } \\
\text { aridity index }<40 \text { and } \\
\text { with the highest } \\
\text { topsoil salinity values }\end{array}$ & 2 & 21 & 15 & 5 & 2 & 45 \\
\hline
\end{tabular}

2 


\section{Table 7 (on next page)}

Geographic description of the Spanish Aegilops populations selected as potentially tolerant to drought and salinity. 


\begin{tabular}{|c|c|c|c|c|c|c|}
\hline Species & Latitude & Longitude & Province & Municipality & $\begin{array}{l}\text { Lang } \\
\text { index }\end{array}$ & $\begin{array}{l}\text { Topsoil } \\
\text { salinity } \\
\text { (dS/m) }\end{array}$ \\
\hline Ae. neglecta & 41.700833 & -0.045000 & Huesca & Villanueva de Sigena & 29 & 2.1 \\
\hline Ae. neglecta & 42.060000 & -0.460000 & Huesca & NA & 36 & 2.1 \\
\hline Ae. neglecta & 41.530000 & -0.840000 & Navarra & El Burgo de Ebro & 26 & 0.8 \\
\hline Ae. neglecta & 41.430000 & -0.360000 & Zaragoza & Pina de Ebro & 27 & 0.8 \\
\hline Ae. neglecta & 41.430000 & -0.720000 & Zaragoza & NA & 28 & 0.8 \\
\hline Ae. neglecta & 41.420000 & -0.240000 & Zaragoza & Bujaraloz & 29 & 0.8 \\
\hline Ae.neglecta & 41.510000 & -0.240000 & Zaragoza & La Almolda & 29 & 0.8 \\
\hline Ae. geniculata & 38.640000 & -0.900000 & Alicante & Villena & 27 & 0.7 \\
\hline Ae. geniculata & 36.736490 & -4.118400 & Málaga & Vélez-Málaga & 23 & 0.7 \\
\hline Ae. neglecta & 41.430000 & -0.480000 & Zaragoza & $\mathrm{NA}$ & 23 & 0.7 \\
\hline Ae. neglecta & 41.520000 & -0.600000 & Zaragoza & Osera de Ebro & 23 & 0.7 \\
\hline Ae. geniculata & 39.137000 & -0.512550 & Valencia & Alberic & 24 & 0.7 \\
\hline Ae. geniculata & 39.227020 & -0.509370 & Valencia & Alginet & 25 & 0.7 \\
\hline Ae. geniculata & 39.936200 & -0.037130 & Castellón & Vila-real & 25 & 0.7 \\
\hline Ae. geniculata & 39.450000 & -0.440000 & Valencia & Burjassot & 25 & 0.7 \\
\hline Ae. geniculata & 39.494530 & -0.383580 & Valencia & Valencia & 25 & 0.7 \\
\hline Ae. geniculata & 39.671850 & -0.260330 & Valencia & Sagunt & 26 & 0.7 \\
\hline Ae. geniculata & 39.260000 & -0.330000 & Valencia & Valencia & 26 & 0.7 \\
\hline Ae. geniculata & 38.603590 & -0.875550 & Alicante & Villena & 26 & 0.7 \\
\hline Ae. geniculata & 39.857140 & -0.486740 & Castellón & Segorbe & 29 & 0.7 \\
\hline Ae. geniculata & 38.856240 & -0.061490 & Alicante & Pego & 29 & 0.7 \\
\hline Ae. geniculata & 40.487170 & 0.463370 & Castellón & Vinaròs & 30 & 0.7 \\
\hline Ae. geniculata & 38.810000 & 0.173000 & Alicante & Jávea & 33 & 0.7 \\
\hline Ae. neglecta & 41.710000 & -4.680000 & Valladolid & Cabezón de Pisuerga & 34 & 0.7 \\
\hline Ae. geniculata & 36.706040 & -4.610470 & Málaga & Cártama & 34 & 0.7 \\
\hline Ae. neglecta & 42.270278 & 3.144444 & Gerona & Roses & 36 & 0.7 \\
\hline Ae. neglecta & 41.360000 & 2.040000 & Barcelona & Barcelona & 37 & 0.7 \\
\hline Ae. neglecta & 42.080000 & -4.570000 & Palencia & Monzón de Campos & 37 & 0.7 \\
\hline Ae. biuncialis & 37.021190 & -4.528030 & Málaga & Antequera & 39 & 0.7 \\
\hline Ae. geniculata & 38.691500 & -0.757980 & Alicante & Beneixama & 30 & 0.7 \\
\hline Ae. geniculata & 39.540000 & -0.550000 & Valencia & Bétera & 26 & 0.6 \\
\hline Ae. geniculata & 37.930000 & -1.170000 & Murcia & Murcia & 17 & 0.6 \\
\hline Ae. ventricosa & 38.869280 & -6.637140 & Badajoz & Lobón & 30 & 0.6 \\
\hline Ae. neglecta & 41.330000 & -0.250000 & Zaragoza & Bujaraloz & 26 & 0.6 \\
\hline Ae. geniculata & 39.046980 & -0.515710 & Valencia & $\begin{array}{l}\text { Villanueva de } \\
\text { Castellón }\end{array}$ & 25 & 0.6 \\
\hline Ae.neglecta & 41.710000 & -0.830000 & Zaragoza & NA & 25 & 0.6 \\
\hline Ae. geniculata & 39.584530 & -0.380200 & Valencia & Valencia & 26 & 0.6 \\
\hline Ae. geniculata & 36.727000 & -4.405000 & Málaga & Málaga & 28 & 0.5 \\
\hline Ae. ventricosa & 38.414300 & -0.423030 & Alicante & El Campello & 20 & 0.4 \\
\hline Ae. triuncialis & 41.790000 & 0.710000 & Lérida & Castellón de Farfaña & 35 & 0.4 \\
\hline
\end{tabular}




\begin{tabular}{|l|r|r|l|l|r|r|}
\hline Ae. biuncialis & 36.850000 & -2.330000 & Almería & Almería & 12 & 0.3 \\
\hline Ae. triuncialis & 38.384490 & -2.804990 & Jaén & La Puerta de Segura & 27 & 0.3 \\
\hline Ae. triuncialis & 40.030000 & -0.250000 & Castellón & Onda & 27 & 0.3 \\
\hline Ae. triuncialis & 39.419940 & -1.199440 & Valencia & Requena & 28 & 0.3 \\
\hline Ae. triuncialis & 39.190000 & -1.490000 & Albacete & Casas Ibáñez & 27 & 0.3 \\
\hline
\end{tabular}

2 
Table 8(on next page)

Number of ELC categories of Aegilops species currently represented in the Spanish Network and potential increase (\%) in representativeness by collecting the predictive characterization subset. 


\begin{tabular}{|c|c|c|c|c|c|}
\hline & $\begin{array}{c}\text { Ae. } \\
\text { biuncialis }\end{array}$ & $\begin{array}{c}\text { Ae. } \\
\text { geniculata }\end{array}$ & Ae. neglecta & $\begin{array}{c}\text { Ae. } \\
\text { triuncialis }\end{array}$ & $\begin{array}{c}\text { Ae. } \\
\text { ventricosa }\end{array}$ \\
\hline $\begin{array}{l}\text { Number of } \\
\text { categories in the } \\
\text { ELC map }\end{array}$ & 26 & 27 & 27 & 27 & 27 \\
\hline $\begin{array}{l}\text { Number of ELC } \\
\text { categories currently } \\
\text { represented in the } \\
\text { Spanish Network }\end{array}$ & 2 & 13 & 7 & 11 & 6 \\
\hline $\begin{array}{l}\text { Percentage of ELC } \\
\text { categories currently } \\
\text { represented in the } \\
\text { Spanish Network }\end{array}$ & 8 & 48 & 26 & 41 & 22 \\
\hline $\begin{array}{l}\text { Number of ELC } \\
\text { categories in the } \\
\text { spatial gaps }\end{array}$ & 9 & 26 & 26 & 22 & 18 \\
\hline $\begin{array}{l}\text { Number of } \\
\text { populations in the } \\
\text { PC subset }\end{array}$ & 2 & 21 & 15 & 5 & 2 \\
\hline $\begin{array}{l}\text { Number of ELC } \\
\text { categories of the } \\
\text { populations in the } \\
\text { PC subset }\end{array}$ & 2 & 3 & 3 & 2 & 2 \\
\hline $\begin{array}{l}\text { Percentage of } \\
\text { improvement in } \\
\text { ecogeographical } \\
\text { representativeness }\end{array}$ & 8 & 11 & 11 & 7 & 7 \\
\hline
\end{tabular}

2

3

4

5

6 